\title{
Malignant hemangiopericytoma of the rectum
}

\author{
JM RADHI, MBCHB, MRCPATH, FRCPC, SU KhaLIQ, MBBS, FRCPATH, PHD, C POWELl, PHD
}

\begin{abstract}
JM RADHI, SU KHALIQ, C POWELL. Malignant hemangiopericytoma of the rectum. Can J Gastroenterol 1993;7(3):297-299. A case of malignant hemangiopericytoma presented as a bleeding rectal polyp is described. The lesion developed 10 years following prolonged chemotherapy treatment for recurrent right breast carcinoma. Hemangiopericytomas are relatively uncommon vascular neoplasms which demonstrate predominantly pericytic differentiation. The neoplasm occurs most frequently in the mesenchymal tissues, but hemangiopericytomas have been described in a variety of sites. Those arising in the gastrointestinal tract are commonly found in the stomach and very rarely in the colon or rectum.
\end{abstract} Key Words: Breast cancer, Chemotherapy, Malignant hemangiopericytoma, Rectum

\section{Hémangiopéricytome malin du rectum}

RÉSUMÉ: Un cas d'hémangiopéricytome malin sous forme de polype rectal hémorragique est décrit ici. La lésion s'est formée 10 ans après l'administration d'un traitement de chimiothérapie prolongé pour un cancer récidivant au sein droit. L'hémangiopéricytome est une néoplasie vasculaire relativement rare qui présente une différenciation principalement péricytaire. La néoplasie survient le plus souvent dans les tissus mésenchymateux, quoique les hémangiopéricytomes aient été décrits en différents sites. Ceux qui proviennent des voies digestives s'observent communément au niveau de l'estomac, et très rarement au niveau du côlon ou du rectum. $\coprod \begin{aligned} & \text { EMANGIOPERICYTOMA IS A RARE } \\ & \text { tumour arising from pericytes, }\end{aligned}$ which are primitive mesenchymal cells closely associated with capillary endothelial cells. The neoplasm occurs most frequently in the mesenchymal soft tissue but hemangiopericytomas have been observed in a number of viscera including brain, oral cavity, thyroid, urinary bladder and prostate (1). He-
Department of Pathology, The Moncton Hospital, and Saint John Regional Hospital, New Brunswick

Correspondence: Dr JM Radhi, The Moncton Hospital, Laboratory Medicine, 135

MacBeath Avenue, Moncton, New Brunswick E1C 6Z8. Telephone (506) 857-5322, Fax (506) $857-5312$

Received for publication September 24, 1992. Accepted October 29, 1992 mangiopericytomas of the gastrointestinal tract occur most frequently in the stomach (2) and ileum (3) but isolated cases have been reported in the esophagus, duodenum, colon, rectum, liver and gall bladder (1).

A rare case of malignant hemangiopericytoma of the rectum in an 89. year-old female, which developed 10 years after chemotherapy treatment for recurrent right breast carcinoma, is described. The patient presented with lower gastrointestinal bleeding and was found to have a rectal polyp. To our knowledge this represents the second case report of this condition. The role of chemotherapy is discussed.

\section{CASE PRESENTATION}

An 89-year-old female patient presented with lower gastrointestinal bleeding for two months associated with lower abdominal discomfort. Physical examination revealed a rectal polyp which was resected. Past medical history included right mastectomy for breast carcinoma in 1977 followed by local recurrence in 1978. The patient received local radiotherapy and hormonal treatment, followed by several courses of chemotherapy for the past 10 years. Her course of treatment was complicated by episodes of leucopenia and thrombocytopenia. Recently, she developed congestive heart failure with 


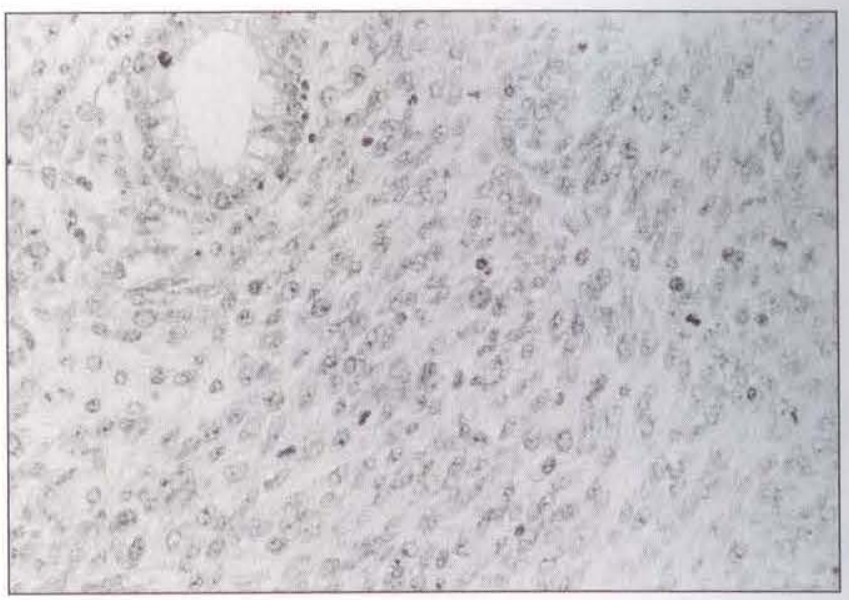

Figure 1) Rectal mucosa infiltrated by spindle and fusiform cellular tumour (Hematoxylin-eosin, x105)

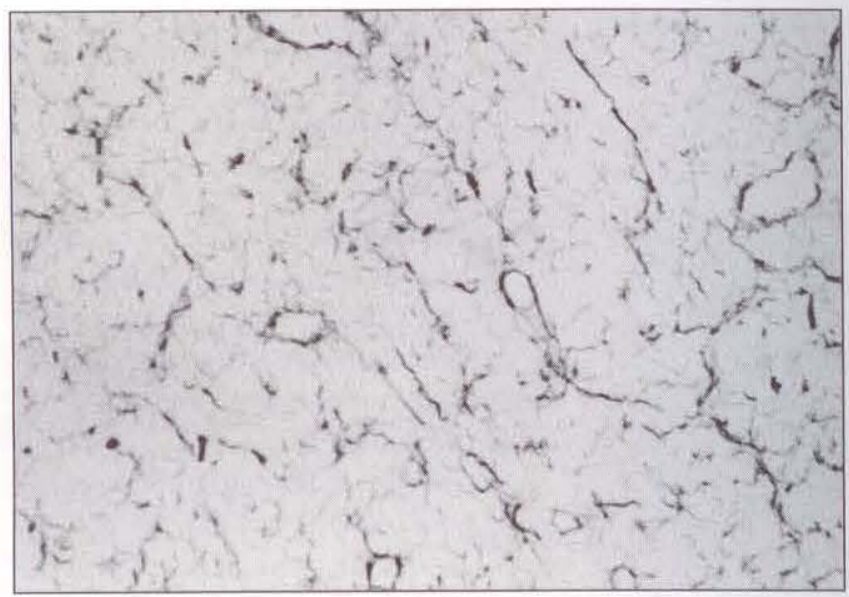

Figure 3) Reticulin stain of tumour revealing vascular spaces and dense reticulin meshwork $(\times 105)$

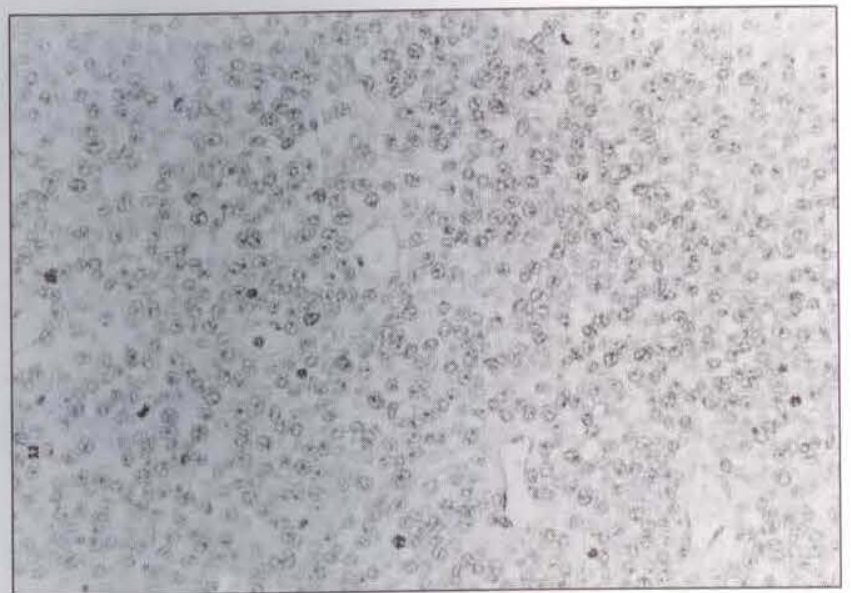

Figure 2) Tightly packed cells with high mitotic activity around vascular spaces (Hematoxylin-eosin, $\mathrm{x} 105$ )

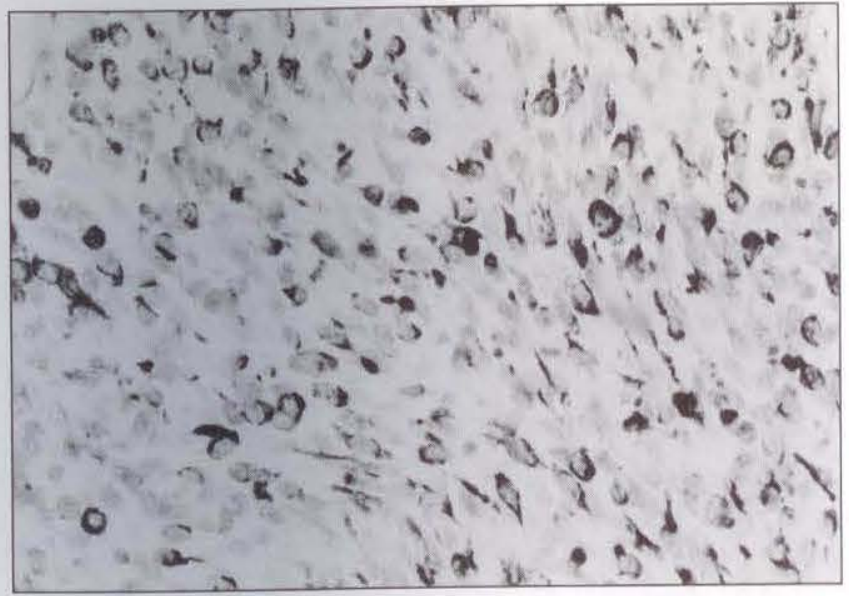

Figure 4) Tumour cells showing strong positive staining with antivimentin marker (Immunoperoxidase, $\mathrm{x}$ 182) massive pleural effusion and died with no post mortem examination.

\section{PATHOLOGICAL FINDINGS}

The specimen consisted of a resected egg-shaped polyp $(3.5 \times 2 \times 2 \mathrm{~cm})$ with a white firm cut surface. Microscopic examination revealed a highly cellular, tightly packed, oval to spindle shaped cell tumour (Figure 1) with round nuclei and prominent nucleoli. Mitoses averaging two to five per 10 high power microscopic fields $(\times 40)$ were seen. The tumour was characterized by abundant branching capillaries lined by flat endothelium (Figure 2). The tumour cells intimately surrounded the vessels but were separated from the latter by a thin sheath of reticulin (Figure 3).

Immunohistochemical stains were performed on paraffin embedded sections using the avidin biotin complex technique for visualization of antibody binding. The following markers were used: epithelial membrane antigen, S100 protein, vimentin, actin, myosin and neuron specific enolase. The tumour cells were positive for vimentin antisera (Dako) (Figure 4) and focally for $\mathrm{S} 100$ protein (Dako); they reacted negative for all other markers. Electron microscopic examination show ovoid nuclei and pale cytoplasm with few rough endoplasmic reticulum, pinocytotic vesicles, mitochondria and occasional myofibrils and discontinous basal lamina.

\section{DISCUSSION}

Hemangiopericytoma is a rare tumour arising from the pericytes of Zimmermann, which are primitive mesenchymal cells closely associated with capillary endothelial cells (4). Hemangiopericytoma usually involves the soft tissue, predomi- nantly in the lower extremities, pelvis and retroperitoneum. It appears to have no predilection for sex or age (5).

Hemangiopericytomas have been noted to arise from all levels of the gastrointestinal tract, stomach (2) and small bowel (3) being the most common sites. Isolated cases have been reported in the esophagus, colon and rectum (1) but these are very rare and, to our knowledge, only one case has been reported in the rectum (6).

Intestinal hemangiopericytoma may present with signs and symptoms of obstruction, intussusception and bleeding (3). Hemangiopericytoma of liver may be associated with hypoglycemia (7). This case, developing in an 89-year-old female almost 10 years after chemotherapy for recurrent breast cancer, is the second report of hemangiopericytoma involving the rectum. The ne- 
crosis and the high mitotic activity indicate malignant hemangiopericytoma (8). The tumour cells were positive for vimentin antisera marker and electron microscopy revealed paucity of cellular organelles in keeping with hemangiopericytoma (9). It is known that immunosuppression results in an increased risk of development of neoplastic lesions and one can postulate that this tumour may have been induced by prolonged chemotherapy treatment.

ACKNOWLEDGMENT: We thank Mrs J Breau for typing the manuscript.

\section{REFERENCES}

1. Gupta S, Padmanabahan A, Knanna S. Malignant hemangiopericytoma of the gallbladder. J Surg Oncol 1983;22:171-4.

2. Cueto J, Gilbert EF, Currie RA. Hemangiopericytoma of the stomach. Am Surg 1966;112:943-6.

3. Ball ABS, Strong L, Hastings A. Malignant hemangiopericytoma of the terminal ileum presenting with peritonitis and transcoelomic metastases. Br J Surg 1984;71:161-2.

4. Stout AP, Murray MR. Hemangiopericytoma - A vascular tumour featuring Zimmermann's pericytes. Ann Surg 1942;116:26-33.

5. Auguste LJ, Razack MS, Sako K.
Hemangiopericytoma. J Surg Oncol $1982 ; 20: 260-4$

6. Kay S, Warthen HJ. Hemangiopericytoma of the rectum. Cancer 1953;6:167-9.

7. Weitzner S. Primary hemangiopericytoma of liver associated with hypoglycemia. Report of a case. Dig Dis 1970;15-7:673-8.

8. McMaster MJ, Soule EH, Ivins TC Hemangiopericytoma. A clinicopathologic study and longterm followup of 60 patients. Cancer 1975;36:2232-44.

9. Nennery EW, Khan LB, Reddick RL, Lipper S. Hemangiopericytoma. A light microscopic and ultrastructural study. Cancer 1981;47:907-14. 


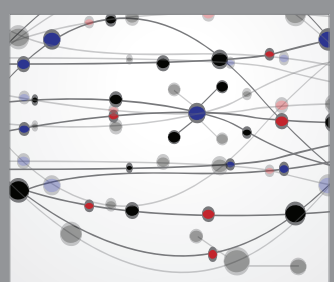

The Scientific World Journal
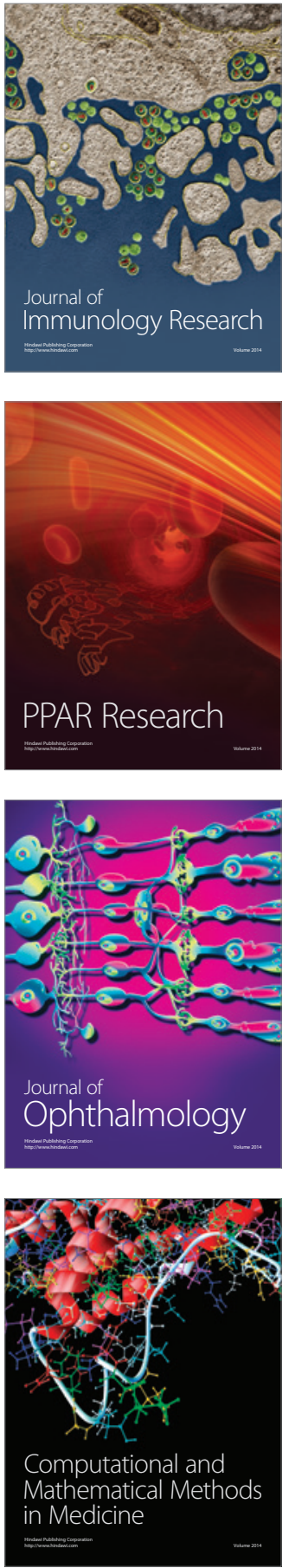

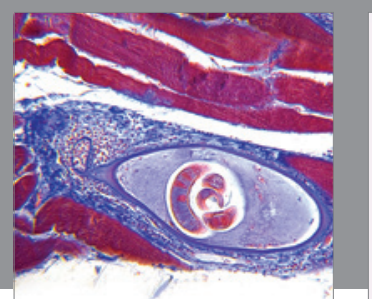

Gastroenterology Research and Practice

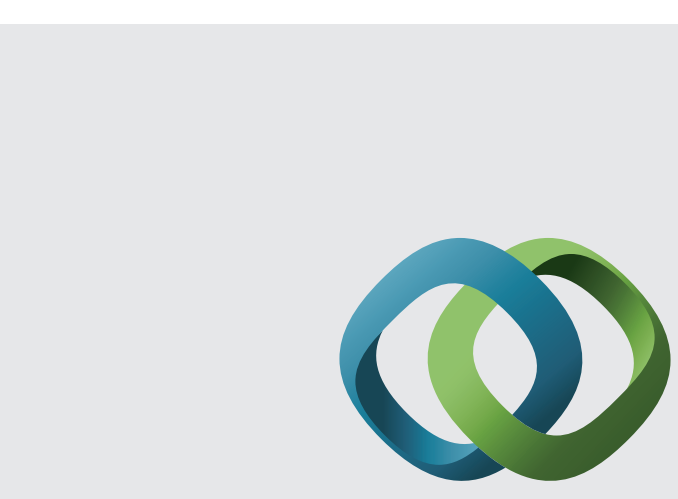

\section{Hindawi}

Submit your manuscripts at

http://www.hindawi.com
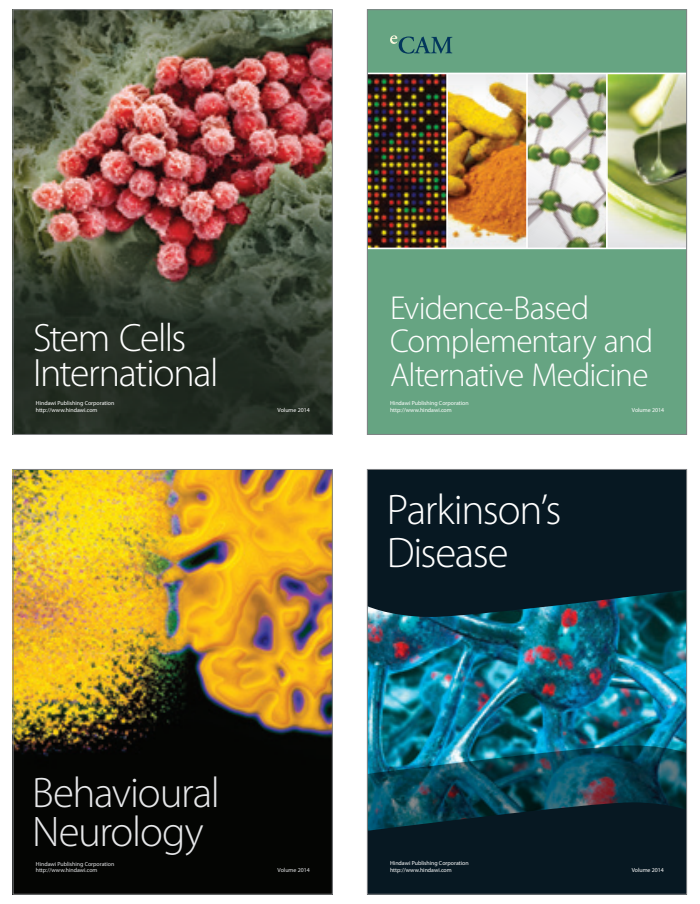
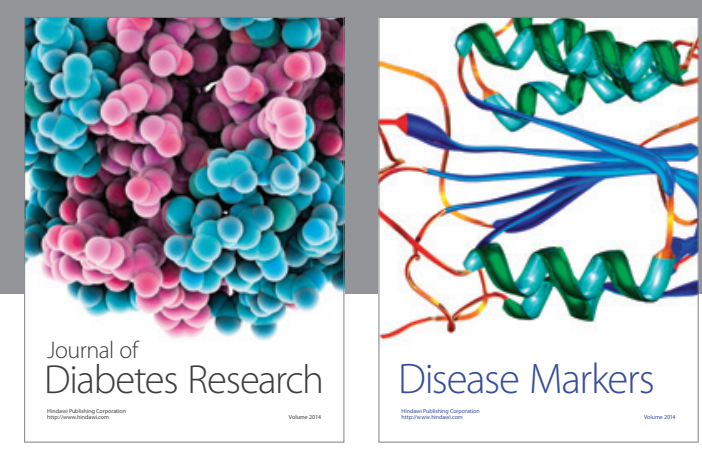

Disease Markers
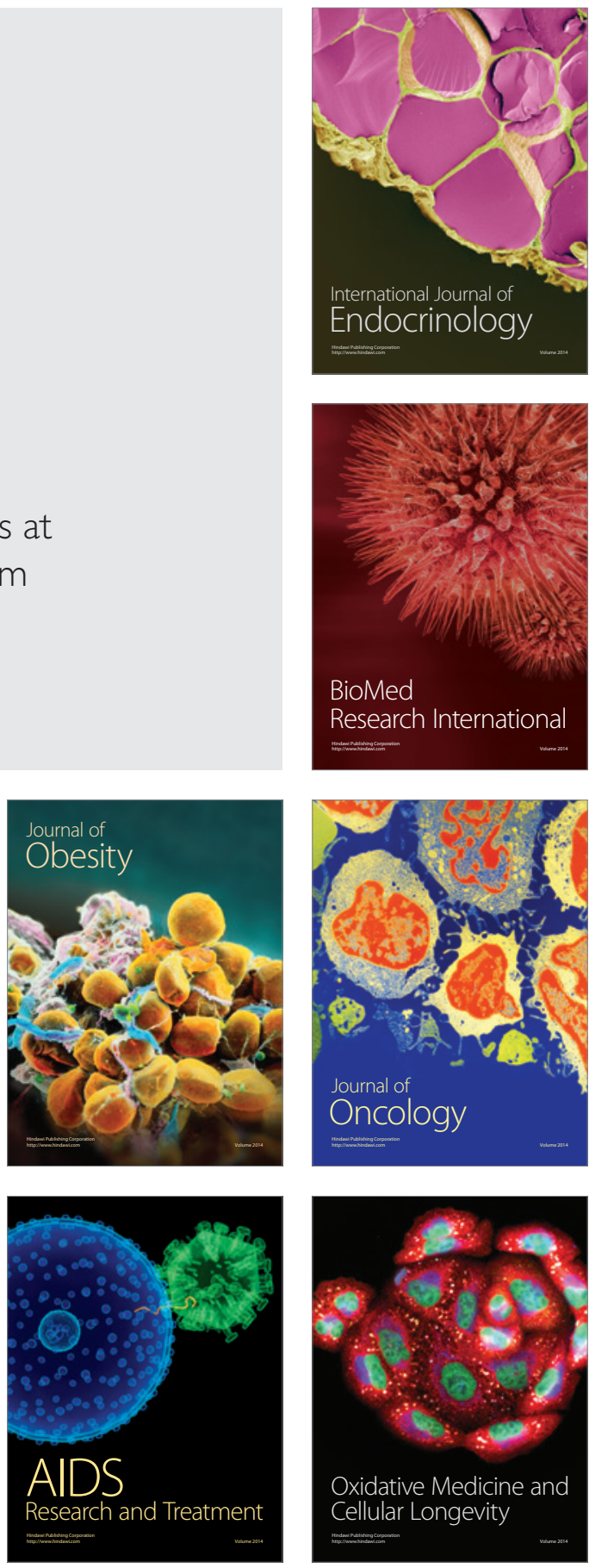